\title{
Mediation Development in Russian Civil Proceedings: some Theoretic Provisions and Pilot Project Results
}

\author{
Svetlana K. Zagaynova and Nikolai N. Tarasov* \\ Ural State Law University \\ 21 Komsomolskaya Str., Yekaterinburg, 620137, Russia
}

Received 23.08.2014, received in revised form 12.10.2014, accepted 24.11.2014

The current article analyzes the main results of the pilot project on the development of mediation in civil legal proceedings carried out by the Mediation Centre of Ural State Law University with the participation of Sverdlovsk Oblast Court and the Directorate of Justice Department in Sverdlovsk Oblast.

Keywords: mediation, mediation models, civil proceedings.

Research area: legal sciences.

As a form of legal dispute resolution Mediation, widely used and recognized in the modern world, is only breaking the ground in Russia. Moreover, it has become clearly visible in the legislation only. With a great share of optimism one may admit that the current legislation (Federal Law "On the alternative procedure of dispute resolution with an intermediary (mediation procedure)" and Federal Law "On introducing amendments into certain legislative acts of the Russian Federation due to the enactment of the Federal Law "On the alternative procedure of dispute resolution with an intermediary (mediation procedure)") has created the sufficient initial conditions for the formation and development of mediation in Russia. At all rates, conciliation of disputing parties is beginning to be recognized as legally significant, or even as a function of some legal professions ${ }^{1}$.

However, in our country not only lawyers are well familiar with the "distance" between the law and regular practice, which the mediation has not yet become in the present nor is it expected to be in the nearest future. The main conditions for the formation and successful development of mediation are: necessary transformations of the public and professional legal consciousness, system maturity and technical precision of the corresponding legal constructions which, unfortunately, currently leave much to be desired, and formation of a qualified mediator community.

It is important to realize that the current situation is already a situation of development, which may not be overcome with the "legislative

(c) Siberian Federal University. All rights reserved

* Corresponding author E-mail address: tarasov@usla.ru 
statement" method. Even reducing the situation to the procedural, organizational and competence conditions, it is too early to expect the wide-spread mediation practice in the nearest future. The tempo of public consciousness transformation is not the only problem. It is important to understand the scale of the organizational tasks to be solved, for instance, the task of training mediators for introducing mediation as a compulsory pre-court conciliation stage. According to the latest statistic data, the regular court alone trials over 15 million civil cases per year. In the event of introduction of compulsory pre-court mediation, the mediation procedure will become essential for at least a half (or even a quarter) of this number, thereby requiring a well-structured body of qualified mediators, in its amount comparable to the whole judicial body of the country. It is no coincidence that in many countries of the world mediation is included into the functions of advocates, corporate lawyers, notaries, legal advisors etc. Unfortunately, Russian legislators are not inclined to such a solution, and our legal community tends to underestimate the prospective of this activity type.

Solving the problem of implementation and development of mediation within the Russian legal system requires both a significant amount of time and sufficient funds. One of the possible ways of performing the work may be creating a series of experimental sites for integrating mediation into the legal practice. In particular, it is proved with the experience of the Mediation Centre of Ural State Law University, a pilot project for implementation of mediation into civil court proceedings in Yekaterinburg $^{2}$. Within the framework of the project aimed at, first of all, teaching mediators and judges, a series of successful solutions for overcoming organizational and procedural problems of mediation practice were found, some suggestions on the amendments to be introduced into the corresponding regulating acts were made, and good results of practical mediation were achieved ${ }^{3}$.

One of the major results of both this project and a series of others was realization of the fact that implementation and development of mediation in Russia is practically impossible without active involvement of the judges' community. However, courts still face a series of significant difficulties connected with the issue. The implementation of the Law on Mediation and introduction of the corresponding amendments into the Civil Procedural Code of the Russian Federation set a task for the courts to take measures for assisting civil process parties to reach amicable agreement, which is also based on the results of a mediation procedure. However, the question on the necessity and forms of interaction between the mediator and the court, complicating the enactment of mediation practice in Russia, still remains unsettled ${ }^{4}$. In its turn, it complicates the enactment of mediation as an institution intended to decrease the caseload ${ }^{5}$. For this reason the problem of reducing judges' effort in civil proceedings and civil case resolution still remains acute.

So, right before the implementation of the Law on Mediation, according to the results of the year 2010, the "caseload leader" of Sverdlovsk Oblast was Oktyabrsky District Court of the City of Yekaterinburg, where 14 judges trialed over 8000 civil cases. The Chief of Oktyabrsky District Court of the City of Yekaterinburg suggested trying the civil case mediation practice. The offer was based on the capacities of the Mediation Centre of Ural State Law University (at that time, Ural State Law Academy), which had been successfully practicing mediation, had had experience on teaching mediation technologies to lawyers, had been carrying out some research on the problems of integrating mediation into legal activity along with wide propaganda among 
citizens and organizations, raising awareness on the advantages of conciliation procedures.

In February 2011 a work group consisting of representatives of Sverdlovsk Oblast Court, Oktyabrsky District Court of the City of Yekaterinburg, USLU Mediation Centre, Directorate of Justice Department in Sverdlovsk Oblast arrived at the following conclusion: in order to make the Law on Mediation "work" in practice, it requires some organizational, procedural and process means for being implemented. Such means may only be developed within the framework of certain numerously trialed and corrected practices. Considering these factors, the work group made a decision to organize a pilot project, as this form was considered to be the most efficient for solving the problems listed above. For the project performance, an appropriate concept and program of works were developed ${ }^{6}$.

The main objective of the project was to find the optimal model for matching the conciliation procedure (mediation) with the civil court proceedings, development of documental forms of interaction between the court and the mediators. In order to achieve the objective, the following tasks were set forward:

1) Development of procedural mechanisms of submitting disputes to mediation at the of pre-court preparation stage;

2) Development of documental forms of submitting disputes to mediation;

3) Development of requirements for the form and content of the mediation agreement, providing the court with the capacity to terminate the proceedings due to the establishment of amicable agreement and withdrawal of claims;

4) Development of a methodology for the court to instruct the parties on their right to settle the dispute with the mediation procedure;
5) Development of a program for teaching judges the methodology for the court to instruct the parties on their right to settle the dispute with the mediation procedure;

6) Development and trial of the methodology of teaching the mediation basics to the judges;

7) Development of a methodology for the judges to implement mediation technologies in civil proceedings;

8) Development of a special program to teach judges the mediation technologies used for civil court proceedings.

The project was planned to be executed from April 01 to December 31, 2011, at Oktyabrsky District Court of the City of Yekaterinburg and the Justice of Peace of judicial area 6 of Oktyabrsky District of the City of Yekaterinburg. As proved by practice, the pilot project activity showed some good results, so the experiment was extended for the years 2012-2013 including some more courts of Sverdlovsk Oblast by the Decree of the Presidium of Sverdlovsk Oblast Court. During the project period, it was participated by 5 district courts of Yekaterinburg and 14 district courts of Sverdlovsk Oblast ${ }^{7}$.

The scientific and methodological provision of the pilot project and mediation practice were carried out by the mediators of the Mediation Centre of Ural State Law University. The issues of organizational, material, technical and financial means were solved by the Directorate of the Justice Department in Sverdlovsk Oblast. To launch the experiment, the USLU Mediation Centre received the grant from USRF, The U.S. Russia Foundation for Economic Advancement and the Rule of Law.

The experiment was run in the three following branches:

1) Teaching judges the basics of mediation, development of the methodology for the 
court to instruct the parties on their right to settle the dispute with the mediation procedure;

2) Advanced teaching of mediation techniques to a group of judges;

3) Performance of civil proceedings' mediation; development of forms and mechanisms of interaction between the mediator and the court.

The pilot project results of the years 20112013 have been collected and analyzed by the present time.

1. Teaching judges the basics of mediation, development of the methodology for the court to explain the right for the dispute settlement with the mediation procedure to the parties. The demand for mediation among the civil proceedings' parties is greatly influenced by the mediation awareness of the judges. As the experience of the USLU Mediation Centre proves, the critical role in making a decision to choose mediation for dispute settlement was played by the fact of being told about such possibility by judges themselves.

For this reason the first step was to carry out a series of introductory seminars "Integrating mediation into civil court proceedings" for the judges involved into civil legal proceedings, judicial assistants and Justice of the Peace. During the legal project three groups of judges and judicial assistants consisting of 102 people were trained according to the program.

At the seminars run by the USLU Mediation Centre specialists the listeners learned the peculiarities of mediation as an alternative way of legal dispute settlement, the methodology for the court to instruct the parties on their right to settle the dispute with the mediation procedure; they determined the procedural mechanisms of submitting disputes to mediation during the pre-trial civil case preparation and during consideration of the case on its merits.
Moreover, within the framework of the training they came up with some recommendations on defining potentially "mediable" and "nonmediable" disputes, and developed the technology of explaining the mediation right. For the judges, the USLU Mediation Centre developed determination criteria of dispute mediability.

At the end of the training, the judges had a better idea of mediation, being able not only to formally declare the right of the parties to submit their dispute to a mediator, but also to explain the significance and advantages of mediation to the parties, the opportunities and limits of this procedure, thereby increasing the number of people preferring mediators' service.

As a result of this work, the number of applications submitted for mediation by civil case parties began to grow.

In September 2011, in order to increase the work efficiency it was decided to organize some information meetings with mediators in the court building. Twice a week the USLU Mediation Centre mediators visited Oktyabrsky District Court of the City of Yekaterinburg to consult the civil legal proceedings' parties on the dispute settlement issues. For this purpose some certain interaction forms were developed by Oktyabrsky District Court of the City of Yekaterinburg and the USLU Mediation Centre. So, the functions of the judge considering the case included the explanation of the right to settle the dispute with the help of a mediator and making an appointment with the mediator. At the appointed day and time the parties came to the meeting. The mediators carried out preliminary consultations, at which they:

- listened to the parties on their merits;

- attracted the parties' attention to the opportunities, advantages and limits of the mediation procedure;

- made the preliminary evaluation of the dispute mediability; 
Table 1

\begin{tabular}{|c|c|c|c|c|}
\hline 2009 & 2010 & 2011 & 2012 & 2013 \\
\hline 7 & 27 & 44 & 129 & 181 \\
\hline
\end{tabular}

- determined the parties involved into the dispute;

- determined the necessity to involve any third parties into the mediation (state authority bodies, local government bodies, organization representatives etc.);

- concluded mediation procedure agreements.

In March 2012, Oktyabrsky District Court of the City of Yekaterinburg opened the first conciliation room in Russia. Today similar rooms are present at other district courts of Yekaterinburg and Sverdlovsk Oblast. This experience has been adopted in some other regions of Russia.

The correctness of the selected way and forms of work is proved by the Table below, illustrating the dynamics of the number of the mediation applications (within the pilot project framework) submitted to the USLU Mediation Centre from the year 2009 to 2013.

2. Teaching mediation techniques to judges. The objective of this work was to study the opportunities of implementing certain mediation techniques in court proceedings to increase the number of amicable agreements in court.

In May 2011, based on the present experience of teaching representatives of different legal professions, the USLU Mediation Centre specialists developed a program "Mediation techniques in court proceedings" for judges.

In June 2011 a special training program was organized for six judges of Sverdlovsk Oblast Court and Oktyabrsky District Court of the City of Yekaterinburg, who wished to prove the capacity of mediation techniques in real practice of court proceedings.

In the process of training, the techniques of communication, negotiation moderation were studied and developed; the basic procedures of mediation and peculiarities of implementing mediation techniques in certain categories of civil cases were reviewed.

As a result, the share of cases terminated by the judges who went through the training program versus the total number of cases considered by them in the year 2011 increased, on the average, by two times in comparison with the same data for the year 2010. The number of cases terminated due to withdrawal of claims increased by 1.5 times; the number of cases terminated due to amicable agreement increased by 1.3 times; the number of cases terminated due to other reasons increased by 3.5 times.

According to the statistic data provided by Oktyabrsky District Court of the City of Yekaterinburg, the share of the terminated cases versus the total number of the cases considered by the judges who have been trained under the program "Mediation techniques in court proceedings", in the year 2010 were $15 \%$ lower than the court average. After the training held in 2011, the share of the terminated and considered cases of the judges increased and exceeded the court average by $200.5 \%$.

In the years 2012-2013 23 judges from 14 courts (Sverdlovsk Oblast Court, District Courts of Yekaterinburg and Sverdlovsk Oblast) were trained under the program "Mediation techniques in court proceedings". The increase in the number of cases terminated due to conciliation of the parties was noticed in this group as well. The analysis proved that this category of judges from Sverdlovsk Oblast enjoyed a great decrease of effort due to the increase in the number of cases terminated without the judgment of the court. There were examples, when some judges 
specialized in children disputes did not issue a single judgment within two years, terminating all the cases with the conciliation of the parties.

3. Civil case mediation. One of the major parts of the pilot project was the practical civil case mediation carried out by the USLU Mediation Centre specialists. First of all, the forms of interaction between the court and the mediators were developed and improved, increasing the number of practical mediations. The statistics of mediations carried out within the framework of the project is demonstrated in the Table below.

Mediations were carried out for the following civil case categories:

Civil-law relation cases: $46 \%$ (including treaty obligation disputes, inheritance disputes, intellectual property disputes, defense of honor and dignity; harm infliction cases);

Family related cases: $21 \%$

Accommodation related cases: $18 \%$

Labor related cases: $9 \%$

Land related cases: $6 \%$

As a rule, the parties consulted a mediator at the stage of pre-court preparation, less frequently in the course of judicial proceedings, appeal proceedings, or enforcement proceedings.

During the work, the following question was raised: based on what document the judge may postpone the judicial proceedings for the conciliation procedure? Experience has proven that it is mostly preferable to postpone the judicial proceedings against a mediation procedure agreement. It is connected to the following reasons:

a) According to the Law on Mediation, the agreement contains the information on the mediation procedure parties and the subject matter of their dispute, thereby individualizing the dispute and proving the parties' consent to settling the dispute by means of mediation;

b) This document establishes the period, during which the mediation procedure is to be
Table 2

\begin{tabular}{|c|c|c|c|c|}
\hline 2009 & 2010 & 2011 & 2012 & 2013 \\
\hline 1 & 18 & 29 & 68 & 87 \\
\hline
\end{tabular}

performed, thereby allowing the judge considering the case determine the period of postponing the judicial proceedings;

c) The agreement is concluded between the dispute parties and the mediator (or the organization facilitating the mediation procedure), which warrants that, firstly, the preliminary mediability appraisal of the dispute has been carried out and the dispute has been defined as mediable, and, secondly, that the parties have agreed on the mediator candidate and this person is ready to carry out the mediation procedure;

d) From the moment of the agreement conclusion, the claim limitation period is suspended (Art. 202 of the Civil Code of the Russian Federation).

The mediation procedure agreement is a legal fact required for the mediation procedure to begin and for the mediation time to be computed.

As the work results show, the average mediation procedure duration is 25 calendar days (minimal duration is 8 days and maximal duration is 60 days). A common practice is postponing mediation meetings for the following reasons:

- necessity to consult any third parties not taking part in the mediation (management, family members, other persons);

- collection of documents for the parties to get familiar with;

- calculation (re-calculation) of the disputed sums;

- wish to consult the parties' representatives (in the event that the representative did not take part in the mediation procedure together with the principal); 
- need for time to think over the opposite party's offer;

- business of the parties;

- force-majeure circumstances (illnesses, accidents etc.).

Forms of terminating practical mediation:

- Conclusion of mediation agreement;

- Continuation of judicial proceedings;

- Mediator's request to terminate the mediation procedure due to its insufficiency (par. 3 Art. 14, Law on Mediation).

During the reference period, $55 \%$ of proceedings were terminated with a mediation agreement. At the same time, the mediation agreements were executed in $100 \%$ of cases. It is interesting to remark that the surveys carried out after the mediation procedure demonstrated the positive effect of mediation, as even in the event of failure to reach conciliation the parties had had the opportunity to get a deeper understanding of each other's positions.

It is worth mentioning that in several cases when the parties made the decision to continue the judicial proceedings, they still concluded an amicable agreement in court. It practice, there were some cases of the parties' continuing the judicial proceedings, receiving the judicial decision, appealing from it, returning to mediation and finally concluding a mediation agreement.

The majority of cases on which mediation agreements were concluded were finished with the termination of proceedings due to the withdrawal of claims. It is caused by the fact that by concluding the mediation agreement the parties settle the conflict between them, while the civil case under judicial proceedings, as a rule, concerns only one of the conflicting parties.
We should also mention that no judicial decrees made in the mediation process (such as case termination and dismissal of an application without prejudice) have been appealed to a higher court.

As a result of the pilot project, the following difficulties of mediation development in civil legal proceedings have been pointed out:

a) civil legal proceeding parties are poorly informed about mediation, the mediator's role in the procedure and peculiarities of the procedure in comparison with judicial proceedings;

b) at the initial stages of the pilot project the parties' representatives opposed mediation, recommending their principals to settle their disputes in court (which is also connected to the wrong idea of the mediation process and their role in it).

The increase in the demand for mediation was undoubtedly influenced by:

a) the qualified explanation of the parties' right to settle the dispute with the mediation procedure by the judges considering the civil cases;

b) performance of information meetings between the mediator and the parties right in the court building;

c) high professionalism of the mediators;

d) introductory mediation training of the judges.

As a whole, the analysis of the course and results of the pilot project allow us claim that mediation in Russia may be a highly promising field for the majority of legal practices; however, the process of its recognition by both public and professional legal conscience is only breaking the ground, requiring some serious efforts of the legal community for the further promotion.

\footnotetext{
The draft of the Federal Law "On Notaries and Notary activity in the Russian Federation" implies a possibility of the Notary's employing some conciliation procedures for coordinating the parties' positions in the notary process; Federal program "Justice" implies inclusion of mediation into the tasks of judicial bailiffs-executors, and the Decree of the Chairman
} 
of the Government of the Russian Federation dated December 29, 2011, sets forward the task on establishing mediation as a compulsory pre-court stage of dispute settlement.

2 Along with the Mediation Centre of USLU, the main participants of the project were: Sverdlovsk Oblast Court, Oktyabrsky District Court of the city of Yekaterinburg, Directorate of Justice Department in Sverdlovsk Oblast.

3 It concerns more than the number of concluded mediation agreements and the performance of such agreements by their parties. The recent researches proved that the majority of the performed mediation processes' participants have evaluated mediation as a preferable means for legal dispute settlement.

4 Judge community has been actively discussing this issue. Expansive discussions took place at the International Conference "Problems of modern judicature and organizing court proceedings in the Russian Federation" (Yekaterinburg, April 12-13, 2012), All-Russia scientific and practical conference "Mediation practice in Russia: problems, difficulties, solutions" (Yekaterinburg, September 14-15, 2012). The conference was attended by over 200 judges from 20 regions of Russia.

5 The explanatory note to the Federal Law "On the alternative procedure of dispute resolution with an intermediary (mediation procedure)" mentions that one of the reasons for developing mediation in Russia is the urge to decrease the caseload falling on the courts.

6 On March 23, 2011, with the Decree of the Presidium of Sverdlovsk Oblast Court the project was approved, gaining the status of the legal experiment "Development and trial of processes for integrating mediation into civil court proceedings". A corresponding Agreement between Sverdlovsk Oblast Court, Directorate of Justice Department in Sverdlovsk Oblast, and Ural State Law Academy was concluded.

7 The Decree of the Presidium of Sverdlovsk Oblast Court dated March 19, 2014, admits that the pilot project achieved the set objectives and showed some good results. Mediation was demanded by civil proceedings' parties, thereby providing the base for further development of mediation in other forms.

\title{
Развитие медиации
}

\section{в гражданском судопроизводстве России:}

некоторые теоретические полагания

\section{и результаты пилотного проекта}

\author{
С.К. Загайнова, Н.Н. Тарасов \\ Уральский государственный юридический университет \\ Россия, 620137, Екатеринбург, ул. Комсомольская, 21
}

В статье анализируются основные результаты пилотного проекта развития медиации в гражданском судопроизводстве, который осуществлялся Центром медиации Уральского государственного юридического университета при участии Свердловского областного суда и Управления судебного департамента в Свердловской области.

Ключевые слова: медиаџия, модели медиации, гражданское судопроизводство.

Научная специальность: 12.00.00 - юридические науки. 